\title{
Yield and Irrigation Water Productivity of Three Varieties of Buffel Grass (Cenchrus ciliaris L.) in the Southern Coastal Plains of Yemen
}

\author{
Khader Balem Atroosh ${ }^{1}$, Gamhuryah Al-Khader Ahmed ${ }^{1}$, Omer Saeed Lardi ${ }^{1}$, Zahrah Ahmed Eissa ${ }^{1}$ \\ \& Azaiez Ouled Belgacem ${ }^{2}$ \\ ${ }^{1}$ National Livestock Research Center, Agricultural Research \& Extension Authority (AREA), Lahej, Yemen \\ ${ }^{2}$ International Center for Agriculture Research in the Dry Areas (ICARDA), Dubai Office, Dubai, UAE \\ Correspondence: Khader Balem Atroosh, National Livestock Research Center, Agricultural Research \& \\ Extension Authority (AREA), Lahej, Yemen. Email: kbatroosh@hotmail.com
}

Received: October 10, $2017 \quad$ Accepted: November 9, $2017 \quad$ Online Published: December 15, 2017

doi:10.5539/jas.v10n1p114 URL: https://doi.org/10.5539/jas.v10n1p114

The research is financed by Arab Fund for Economic and Social Development (AFESD) and International Fund for Agricultural Development (IFAD).

\begin{abstract}
Small stakeholder farmers in southern coastal plains of Yemen as in other Arabian Peninsula countries are fanciers and suffering from shortage of forages mainly during winter season. This study was carried out during three years (2012-2014) at farmers' fields in the southern coastal plain in Bir Jabir, Lahej in Yemen on loamy-sand soil, to determine the best irrigation water productivity of two exotic and one indigenous (local) accessions of buffel grass (Cenchrus ciliaris L.), cultivated at two farmer fields. Irrigation water has been added by the quantity and dates according to the farmer experience without any intervention of the researcher. The amount of added irrigation water was measured. Statistical analysis emphasized significant differences in the number of tillers per plant, in the forage fresh yield and in the irrigation water productivity (IWP) among buffel grass accessions. The highest number of tillers was recorded at Gayandah whereas the USA accession has showed the lowest one. The average forage fresh yields have reached $230.5,208.9$ and $181.4 \mathrm{~kg} / \mathrm{ha}$ for Gayandah, USA and local respectively. The average irrigation water productivity (IWP) was $39.1 \mathrm{~kg} / \mathrm{m}^{3}$. The significant difference $(P=0.048)$ was in favor of Gayandah accession which registered the highest IWP $\left(43.7 \mathrm{~kg} / \mathrm{m}^{3}\right)$. However, there was no significant difference observed in IWP between USA and the local accession, even though this latter has apparently produced the lowest value $\left(36.2 \mathrm{~kg} / \mathrm{m}^{3}\right)$.
\end{abstract}

Keywords: alternative forage, buffel grass (Cenchrus ciliaris L.), small stakeholders, yield, irrigation water productivity

\section{Introduction}

Fodders and pasture considered an essential substrate for the growth and development of livestock, considered as perfecter of agricultural wealth and has advantage to human needs of animal protein and dairy and other animal products.

Feed scarcity is the main constraint to livestock production in dry areas. This scarcity is exacerbated by rangeland degradation and the recurrent droughts linked to desertification and climate change. Alternative feeds were proposed to alleviate grazing pressure on natural rangelands and to mitigate desertification (Abbeddou et al., 2010).

Livestock is considered as one of the most important economic resource for a wide cross-section of members of the Yemeni people either in the rural or the urban areas. The total number of animals is about 20,552,655 of which $9,357,605$ sheep, 9,105,811 goats, 1,653,672 cattle and 435,567 heads of beauty. Due to the scarcity of water resources in most areas of Yemen, natural rangelands and forage production do not cover the animals needs during the most seasons of the year. In fact, the annual feed production reaches 1,970,540 tons produced from 155,248 hectares (Agricultural Statistical Year Book-2011), seems to be very low and imposes the necessity of looking for other alternative more productive forages with higher water use efficiency. 
Small stakeholder farmers in southern coastal plains of Yemen similarly to other areas from the Arabian Peninsula countries are fanciers, suffering from shortage of forages mainly during winter season. Within the framework of the Arabian Peninsula Regional Program (APRP) "Improving food security and sustainable natural resources management through enhancing integrated agricultural production systems in the Arabian Peninsula" supported by Arab Fund for Economic and Social Development (AFESD) and International Fund for Agricultural Development (IFAD), some forages and fodder crops were screened and their performance under moderate to high water stress conditions. Buffel grass (Cenchrus ciliaris), the indigenous species has been identified as the forage that offers high-quality feed and high water-use efficiency (Mazahreh et al., 2016). Buffel grass a native species of southern Asia and East Africa, and is an excellent forage species and is used in many countries (Lonsdale, 1994; Shinde et al., 1998; Sanderson et al., 1999). It is a robust, deep-rooted C4 perennial tussock grass native to tropical and sub-tropical arid environments (Sharif-Zadeh \& Murdoch, 2001). In terms of nutritional value, buffel grass contains $6-16 \%$ crude protein and digestibility, $50-60 \%$, depending on age of growth, cultivar, and soil fertility (incl. fertilizer use). Phosphorus levels are usually higher than in other tropical grasses and range from $0.15-0.65 \%$ DM (Cook, 2007). Buffel grass is a perennial forage that tolerates semi-arid conditions, grazing and is not very exigent in soil fertility (Araujo Filho, 1988).

The water productivity concept is based on "more crop per drop" or "producing more food from the same water resources" or "producing the same amount of food from less water resources". In a broad sense, productivity of water is related to the value or benefit derived from the use of water (Dam \& Malik, 2003). Molden et al. (1997) defined water productivity as the ratio of beneficial output sand services to water depleted in producing them, which could be expressed in terms of amount (e.g. $\mathrm{kg}$ grain per $\mathrm{m}^{3}$ of water) or value (e.g. USD per $\mathrm{m}^{3}$ of water).

Water productivity can be improved by increasing yield per unit of the land area using a better crop variety, improved agronomic practices, or by growing the crop during the most suitable period. Thus, water productivity can be achieved by factors other than water management (Shideed et al., 2005).

Strategies and policies to reduce rural poverty should not only target increasing food production but should also emphasize improving water productivity (WP) at farm, landscape, sub-basin and higher levels. In drought-prone rural areas, an increase of $1 \%$ in crop water productivity makes available at least an extra 24 litres of water a day per person (FAO, 2003). There are proven interventions that would improve water productivity in these systems. Interventions focused on improving feed management, water management and livestock management had a positive effect on improving water productivity (Peden et al., 2009) ranging from a potential 4 to $94 \%$ improvement (Descheemaeker et al., 2011).

The objective of this study was to determine the best irrigation water productivity of three buffel grass varieties under farmer field conditions in southern coastal plains of Yemen.

\section{Materials and Methods}

This study was carried out during the years 2012, 2013 and 2014 at two farmers' fields in the southern coastal plain in Bir Jabir, Lahej in Yemen on loamy sand soil. Climate in the study area is characterized by hot and humid, where the rainfall is rarely more than $60 \mathrm{~mm} /$ year and less than evapotranspiration during the whole year. The mean maximum temperature is about $31.2^{\circ} \mathrm{C}$ during the month of June when the highest value reaches $38.1{ }^{\circ} \mathrm{C}$. The mean minimum temperature is $23.6{ }^{\circ} \mathrm{C}$ during the month of December, with a lowest value $19{ }^{\circ} \mathrm{C}$ that can be registered either in December or January. The maximum air humidity reaches $74 \%$ during the month of April and the lowest air humidity 64\% through August. Wind speed ranging from 1.1 to $5.1 \mathrm{~m} / \mathrm{s}$, and sunshine ranging between 7.2-9 hours/day, while the daily evapotranspiration ranging from 3.35 to $5.31 \mathrm{~mm} /$ day (Table $1)$. 
Table 1. Climatic characteristics and evapotranspiration in the study area (latitude $13^{\circ} 01^{\prime} \mathrm{N}$, longitude $45^{\circ} 00^{\prime} \mathrm{E}$, altitude $200 \mathrm{~m}$ )

\begin{tabular}{lllllllllllll}
\hline Month & Jan. & Feb. & Mar. & Apr. & May & Jun. & Jul. & Aug & Sep. & Oct. & Nov. & Dec. \\
\hline $\mathrm{T}_{\max },{ }^{\circ} \mathrm{C}$ & 29.1 & 29.2 & 31.3 & 33.6 & 35.8 & 38.1 & 38 & 38 & 34.9 & 34 & 31.5 & 29.3 \\
$\mathrm{~T}_{\min },{ }^{\circ} \mathrm{C}$ & 19 & 20 & 21 & 22 & 24.1 & 25.7 & 26 & 26 & 24.4 & 21 & 19.8 & 19 \\
$\mathrm{~T}_{\text {mean }},{ }^{\circ} \mathrm{C}$ & 24.1 & 24.9 & 25.3 & 27.4 & 29.3 & 31 & 31 & 31 & 30.5 & 27 & 25.5 & 23.6 \\
Air humidity, \% & 72 & 73 & 73 & 74 & 72 & 65 & 65 & 64 & 67 & 69 & 71 & 72 \\
Wind speed, $\mathrm{m} / \mathrm{s}$ & 1.4 & 1.3 & 1.5 & 1.2 & 1.2 & 1.2 & 1.3 & 1.4 & 1.1 & 1.5 & 1.1 & 1.2 \\
Radiation, MJ/m $/$ /day & 17.3 & 18.6 & 21.5 & 23.7 & 23.2 & 22.5 & 21 & 22 & 21.9 & 21 & 19.7 & 18.4 \\
Sunshine, hour & 7.2 & 7.1 & 8.2 & 9.2 & 9 & 8.8 & 7.5 & 8 & 8.4 & 8.8 & 8.8 & 8.4 \\
$\mathrm{ET}_{\mathrm{O}}, \mathrm{mm} /$ day & 3.7 & 3.9 & 4.6 & 5 & 5.2 & 5.4 & 5.2 & 5.5 & 5.1 & 5.1 & 4.3 & 3.9 \\
\hline
\end{tabular}

Source: National Livestock Research Center, Lahej, Yemen.

The following three varieties or cultivars of buffel grass (locally called Libid or Al Zila) were used for this study: The variety Gayandah: introduced from Australia but originally from Kenya. Fine, medium-short (commonly 30-60 cm tall), tufted, non-rhizomatous type, mid-season flowering, suitable for light to medium textured soils. Densily tillered and tolerant of heavy grazing.

The variety USA is a medium height variety that has the fine stems and dense foliage of Gayndah, but it flowers a little earlier and the seed heads are purple in colour. This cultivar is very similar to Gayndah in characteristics and performance, but is shorter and the leaves are laxer and narrower. It is a deep rooted summer growing perennial with drought resistance and tolerant to heavy grazing or burning. The native variety is a vertical buffel grass, locally called $\mathrm{Al}$ Zila and prevalent in the various Yemeni rangelands.

The target fields cover an area of one ha have been prepared and divided into basins with area of $30 \mathrm{~m}^{2}(5 \times 6)$ meters. Seeds of studied varieties were sowed at $5 \mathrm{~cm}$ depth on June 7, 2012. Planting distances were $50 \mathrm{~cm}$ between rows and $30 \mathrm{~cm}$ between plants.

Irrigation water has been added by the quantity and dates according to the farmer experience without any intervention by the researcher. The amount of added irrigation water was measured through measurements of the well discharge and time used to irrigate the basins, according to the following Equation (1):

$$
I W A=\frac{Q 60 T}{\mathrm{~F}}
$$

Where,

$I W A=$ irrigation water applied, $\mathrm{mm} ; Q=$ well discharge, $1 / \mathrm{s} ; T=$ time of irrigation, $\min$.

Irrigation water productivity (IWP) was determined by using the Equation (2):

$$
I W P=\frac{Y}{I W A}
$$

Where,

$I W P=$ irrigation water productivity, $\mathrm{Kg} / \mathrm{m}^{3} ; Y=$ yield, $\mathrm{Kg} / \mathrm{ha} ; I W A=$ irrigation water applied, $\mathrm{m}^{3}$.

The observed data of growth and productivity were recorded at each cutting, plants were cut when reaches stage of spike formation and before the maturity of seeds and at the level of $5 \mathrm{~cm}$ from the soil surface. The design of randomized complete block was used in three replications, while statistical analysis was performed of the obtained data by using the software program Genstat 5 (Lane \& Payne, 1996).

\section{Results and Discussion}

\subsection{Irrigation Water Applied (IWA)}

During the growing period of first cutting, there were six irrigation additions in the first field, while in the second one there were five additions. The amount of applied water were 2810 and $2740 \mathrm{~m}^{3}$ for the first and second fields respectively (Table 3). The total irrigation water applied during the years of study at the first and second fields respectively were, 465 and $452 \mathrm{~mm}$ during 2012, 592 and $551 \mathrm{~mm}$ during 2013 and 528 and $434 \mathrm{~mm}$ during 2014, while the added water for each watering ranged from 52 to $66 \mathrm{~mm}$. On the other hand, the number of irrigations for each year ranges from 7 to 10 watering's (Table 2). 
Table 2. Irrigation Water Applied and cuttings during the years of study

\begin{tabular}{llllll}
\hline \multirow{2}{*}{ Years } & \multirow{2}{*}{ Field } & \multicolumn{4}{c}{ Irrigation Water Applied, mm } \\
\cline { 3 - 6 } & & Number & mm/year & mm/irrigating & Number of Cuttings \\
\hline 2012 & 1 & 9 & 465 & 52 & 2 \\
& 2 & 10 & 452 & 57 & 2 \\
2013 & 1 & 10 & 592 & 59 & 10 \\
& 2 & 8 & 528 & 55 & 10 \\
& 1 & 7 & 434 & 66 & 8 \\
\hline
\end{tabular}

Table 2 shows that the number of irrigations and the quantities of water applied during 2012 were higher than those provided in 2013 and 2014. This is due to the difficulty of plant growth in the early stages of its life on the one hand and on the other hand to the small size of the root mass with limit vegetation cover. In fact, the evaporation of water exceeds the capacity of the root mass absorption, which requires more water, especially during the first and second cuttings in comparison to the subsequent cuttings.

\subsection{Productivity Characteristics at the First Cutting}

The emergence started 15 days after sowing. The percentages of emergence reached 85,75 and $70 \%$ for the varieties Gayandah, USA and Local respectively (Table 3). The absent pits were planted on June $25^{\text {th }}, 2012$ and the first cutting was done on September $23^{\text {rd }}$, 2012. Cook (2007) reported that buffel grass is characterized by a slow establishment rate and grazing may need accordingly to be delayed anything up to 12 months.

Table 3. Morphological and productivity characteristics of buffel grass varieties at the first cutting

\begin{tabular}{|c|c|c|c|c|c|c|}
\hline Fields & \multicolumn{3}{|c|}{1} & \multicolumn{3}{|c|}{2} \\
\hline Variety & Gayandah & USA & Local & Gayandah & USA & Local \\
\hline Number of irrigations & 6 & 6 & 6 & 5 & 5 & 5 \\
\hline Emergence percentage, $\%$ & 65 & 50 & 50 & 85 & 75 & 70 \\
\hline Plant height, $\mathrm{cm}$ & 103 & 81 & 76 & 104 & 80 & 76 \\
\hline Number of tillers $/ \mathrm{m}^{2}$ & 120 & 83 & 90 & 128 & 71 & 90 \\
\hline IWA, $\mathrm{m}^{3}$ & 2810 & 2810 & 2810 & 2740 & 2740 & 2740 \\
\hline Yield, Ton/ha & 35 & 26 & 25 & 33 & 21 & 25 \\
\hline IWP, $\mathrm{Kg} / \mathrm{m}^{3}$ & 12.5 & 9.3 & 8.9 & 12.0 & 7.6 & 9.1 \\
\hline
\end{tabular}

The top plant height at the first cutting was recorded at Gayandah variety $(104 \mathrm{~cm})$ and the lowest plant height was recorded at local variety $(76 \mathrm{~cm})$. The number of tillers at the first cutting was also varying in relation to the variety. In both farms, the highest values (120 and 128) were recorded at Gayandah, while the USA has produced the lowest ones ( 83 and 71$)$. The local variety showed an intermediate vegetative growth with 90 tillers in both farms (Table 3). The fresh matter yields of buffel grass varieties at the first and second fields respectively were 35 and 33 for Gayandah, 26 and 21 for USA and 25 for local variety. Irrigation water productivities (IWP) for the first cutting were about 12,8 and $9 \mathrm{~kg} / \mathrm{m}^{3}$ for Gayandah, USA and local varieties respectively (Table 3 ).

It is shown from the above tables, that the variety Gayandah has shown the best vegetative growth and vigor parameters expressed by plant height, number of tillers and yields. The local variety comes second and showed better performances at this stage than USA variety. This could be explained by its higher adaption especially in the first cutting to the local environmental conditions. However and as it will be shown later, the picture will differ during the subsequent cuttings.

\subsection{Number of Tillers and Forage Fresh Yield}

During the years of study, buffel grass variety Gayandah recorded the highest number of tillers per $\mathrm{m}^{2}$, followed by the local variety and then the USA variety, where the number of tillers per $\mathrm{m}^{2}$ of the studied varieties Gayandah, USA and local respectively were 124,77 and 90 in 2012 at (SE $=5.03$ and $C V \%=7.3), 144,97$ and 104 in 2013 at $(\mathrm{SE}=7.37$ and $\mathrm{CV} \%=9.1)$ and 118,106 and 104 in 2014 at $(\mathrm{SE}=4.07$ and $\mathrm{CV} \%=5.3)(\mathrm{Table}$ 4). Tiller numbers are important for grass plants adaptability and survival under grazing pressure since they 
determine photosynthetic rates and ultimately the food reserves (Laidlaw, 2005). The number of tillers and leaves in a grass plant determines the rate of biomass accumulation and the quality of forage (Skinner \& Moore, 2007).

Table 4. Yield and irrigation water productivity during the 3 years' experimental period (2012-2014).

\begin{tabular}{|c|c|c|c|c|c|c|c|c|c|}
\hline & \multicolumn{3}{|c|}{2012} & \multicolumn{3}{|c|}{2013} & \multicolumn{3}{|c|}{2014} \\
\hline & Tillers $/ \mathrm{m}^{2}$ & $\begin{array}{l}\text { Yield, } \\
\text { ton/ha }\end{array}$ & $\begin{array}{l}\text { IWP, } \\
\mathrm{kg} / \mathrm{m}^{3}\end{array}$ & Tillers $/ \mathrm{m}^{2}$ & $\begin{array}{l}\text { Yield, } \\
\text { ton/ha }\end{array}$ & $\begin{array}{l}\text { IWP, } \\
\mathrm{kg} / \mathrm{m}^{3}\end{array}$ & Tillers $/ \mathrm{m}^{2}$ & $\begin{array}{l}\text { Yield, } \\
\text { ton/ha }\end{array}$ & $\begin{array}{l}\text { IWP, } \\
\mathrm{kg} / \mathrm{m}^{3}\end{array}$ \\
\hline Gayanda & 124.0 & 74.0 & 16.2 & 144.0 & 404.9 & 58.7 & 118.0 & 212.5 & 43.7 \\
\hline USA & 77.0 & 63.4 & 13.9 & 97.0 & 376.8 & 54.6 & 106.0 & 186.5 & 32.3 \\
\hline Local & 90.0 & 57.5 & 12.6 & 104.0 & 329.6 & 47.9 & 104.0 & 157.0 & 38.4 \\
\hline Mean & 97 & 65 & 14.22 & 115.0 & 370.4 & 53.73 & 109.0 & 185.3 & 38.13 \\
\hline LSD & 30.63 & 12.12 & 2.552 & 44.82 & 71.27 & 13.73 & 24.78 & 31.96 & 3.196 \\
\hline $\mathrm{CV} \%$ & 7.3 & 4.3 & 4.2 & 9.1 & 4.5 & 4.9 & 5.3 & 4 & 1.9 \\
\hline P-value & 0.041 & 0.054 & 0.050 & 0.076 & 0.087 & 0.100 & 0.216 & 0.035 & 0.008 \\
\hline
\end{tabular}

The average number of tillers per $\mathrm{m}^{2}$ was 106.9. The lowest (93.2) was with buffel grass variety USA while the highest (128.7) was recorded in the variety Gayandah (Table 5). There were significant differences observed in the number of tillers per plant among buffel grass varieties $(\mathrm{P}=0.036)$. These results are in agreement with Koech et al. (2016).

Table 5. The mean yield and irrigation water productivity of the 3 studied buffel grass varieties during the period 2012-2014

\begin{tabular}{llll}
\hline Variety & Tillers $/ \mathrm{m}^{2}$ & Yield, ton $/ \mathrm{ha}$ & $\mathrm{IWP}, \mathrm{kg} / \mathrm{m}^{3}$ \\
\hline Gayndah & 128.7 & 230.5 & 43.7 \\
USA & 93.2 & 208.9 & 37.4 \\
Local & 99.0 & 181.4 & 36.2 \\
Grand mean & 106.9 & 206.9 & 39.1 \\
LSD & 27.9 & 3.67 & 6.21 \\
C.V. \% & 20.9 & 14.2 & 12.7 \\
P-value & 0.036 & 0.039 & 0.048 \\
\hline
\end{tabular}

Gayandah variety produced the highest forage fresh yield $(404.9 \mathrm{~kg} / \mathrm{ha})$ in the year 2013 , while the lowest forage fresh yield $(57.5 \mathrm{~kg} / \mathrm{ha}$ ) was produced by the Local variety of buffel grass in the year 2012 (Table 4). The mean forage fresh yield of the studied varieties Gayandah, USA and local respectively were 230.5, 208.9 and 181.4 $\mathrm{kg} / \mathrm{ha}$, where the grand mean was 206.9, $\mathrm{LSD}=3.68, \mathrm{CV} \% 14.2$ (Table 5). There were significant differences observed in the forage fresh yield among buffel grass varieties $(\mathrm{P}=0.039)$.

\subsection{Irrigation Water Productivity}

The number of cuttings and the number of added irrigations during the experimental period ( 3 years) are presented in the Table 4. In 2012, there are 9 and 8 irrigations were provided in the fields 1 and 2 respectively, which exceeds the number of irrigations during the subsequent years. In fact, 2012 corresponds to the establishment year and where the two cuttings have expended 108 and 55 days respectively which have led to add accordingly six and three irrigations after each cut. In 2014, the number of irrigations was reduced to eight and seven due to lack of fuel needed to run water pumps from wells. In 2013 the number of irrigations was 10. During 2013 and 2014 the number of irrigations was equal to the number of cuttings.

The obtained annual irrigation water productivity (IWP) of buffel grass varieties Gayandah, USA and local were 16.2, 13.9 and 12.6 respectively in 2012 at $(\mathrm{SE}=0.419$ and $\mathrm{CV} \%=4.2), 58.7,54.6$ and 47.9 in 2013 at $(\mathrm{SE}=$ 2.26 and $\mathrm{CV} \%=4.2)$ and $43.7,32.3$ and $38.4 \mathrm{~kg} / \mathrm{m}^{3}$ in 2014 at $(\mathrm{SE}=0.525$ and $\mathrm{CV} \%=1.9)$ (Table 6).

Table 6. Yield and irrigation water productivity during the years of study 


\begin{tabular}{|c|c|c|c|c|c|c|c|c|c|}
\hline & \multicolumn{3}{|c|}{2012} & \multicolumn{3}{|c|}{2013} & \multicolumn{3}{|c|}{2014} \\
\hline & Tillers $/ \mathrm{m}^{2}$ & $\begin{array}{l}\text { Yield, } \\
\text { ton/ha }\end{array}$ & $\begin{array}{l}\text { IWP, } \\
\mathrm{kg} / \mathrm{m}^{3}\end{array}$ & Tillers $/ \mathrm{m}^{2}$ & $\begin{array}{l}\text { Yield, } \\
\text { ton/ha }\end{array}$ & $\begin{array}{l}\text { IWP, } \\
\mathrm{kg} / \mathrm{m}^{3}\end{array}$ & Tillers $/ \mathrm{m}^{2}$ & $\begin{array}{l}\text { Yield, } \\
\text { ton/ha }\end{array}$ & $\begin{array}{l}\text { IWP, } \\
\mathrm{kg} / \mathrm{m}^{3}\end{array}$ \\
\hline Gayandah & 124.0 & 74.0 & 16.2 & 144.0 & 404.9 & 58.7 & 118.0 & 212.5 & 43.7 \\
\hline USA & 77.0 & 63.4 & 13.9 & 97.0 & 376.8 & 54.6 & 106.0 & 186.5 & 32.3 \\
\hline Local & 90.0 & 57.5 & 12.6 & 104.0 & 329.6 & 47.9 & 104.0 & 157.0 & 38.4 \\
\hline Mean & 97 & 65 & 14.22 & 115.0 & 370.4 & 53.73 & 109.0 & 185.3 & 38.13 \\
\hline LSD & 30.63 & 12.12 & 2.552 & 44.82 & 71.27 & 13.73 & 24.78 & 31.96 & 3.196 \\
\hline CV\% & 7.3 & 4.3 & 4.2 & 9.1 & 4.5 & 4.9 & 5.3 & 4 & 1.9 \\
\hline P-value & 0.041 & 0.054 & 0.050 & 0.076 & 0.087 & 0.100 & 0.216 & 0.035 & 0.008 \\
\hline
\end{tabular}

The mean IWP was $39.1 \mathrm{~kg} / \mathrm{m}^{3}$ with $\mathrm{LSD}=6.21$ and $\mathrm{CV} \%=12.7$. The lowest was recorded with buffel grass local variety 36.2 while the highest was observed at variety Gayandah $43.7 \mathrm{~kg} / \mathrm{m}^{3}$, (Table 5). There were significant differences observed in the IWP among buffel grass varieties $(\mathrm{P}=0.048)$. Given the value of LSD, there were no significant differences between the USA and local varieties, but the significant differences were found between the Gayandah and the other varieties.

In the literature, the studies on comparing in term of water productivity between buffel grass varieties were rare. Most of studies were comparing buffel grass to other grass species. The relatively high water productivity of all studied buffel grass varieties confirms Owens et al. (2008) who showed that buffel grass was the most persistent and drought tolerant species, producing the highest pasture growth and maintaining high cover even in the dry year. These authors found that buffel grass had a significantly higher water use efficiency at 3 years old. In this context, Ahmed et al. (2010) have also showed that under UAE environmental conditions, local buffel grass was the highest producer of dry matter (DM) under all irrigation treatments. Its average yield was 14.6 and $15.1 \mathrm{t} / \mathrm{ha}$ in two seasons, which was significantly higher than other grasses such as Rhodes grass. Buffel grass had the highest WUE value in the two seasons $\left(0.7\right.$ and $\left.0.8 \mathrm{~kg} \mathrm{DM} / \mathrm{m}^{3}\right)$ which was significantly higher over the other grasses. Buffel grass showed the highest increase in WUE in both seasons when irrigation was reduced. The same authors suggest that native desert grasses such as buffel grass could replace exotic Rhodes grass in the cropping system of the Arabian Peninsula in order to save irrigation water.

\section{Conclusion}

The results of the study have emphasized the best performances of buffel grass variety Gayandah compared with USA and local buffel grass varieties. Significant differences were observed at the level of number of tillers per plant, forage fresh yield and irrigation water productivity. Since the highest was recorded at buffel grass variety Gayandah and the lowest at buffel grass variety USA. For all scored parameters, the variety Gayandah has shown the highest values. On the other hand, the Local variety which is supposed to be the well adapted to the local environmental conditions of Yemen seems to have better production characteristics than the introduced varieties under rainfed conditions. This adaptation is expressed by the low vigor and biomass in order to withstand drought and heat stress. Under irrigation, Buffel grass var. Gayandah seems to be the most water use efficient and accordingly the most suitable alternative fodder that need to enhance its adoption by farmers in the southern coastal plain of Yemen.

\section{Acknowledgements}

The authors express thanks and gratitude to all who contributed in implementation and success of this activity particularly, Arabian Peninsula Regional Program (APRP) under umbrella of ICARDA and Arab Fund for Economic and Social Development (AFESD) and International Fund for Agricultural Development (IFAD) respectively who sponsored this work.

\section{References}

Abbeddou, S., Hess, H. D., Hilali, M., Rischkowsky, B., \& Kreuzer, M. (2010). Effect of alternative feeds characteristic for Mediterranean dry areas on the quality of milk dairy products fr-Muhi-El-Dine Awassi sheep. 10th International Conference on Development of Dry lands Meeting, the Challenge of Sustainable Development in Dry lands under Changing Climate-Moving from Global to Local, Dec. 12-15, 2010, Cairo, Egypt.

Ahmed, E., Makawi, M., \& Ahmed, R. (2010). Productivity and water use efficiency of five grasses in United Arab Emirates. 10th International Conference on Development of Drylands Meeting the Challenge of 
Sustainable Development in Drylands under Changing Climate-Moving from Global to Local, Dec. 12-15, 2010, Cairo, Egypt.

Araujo Filho, J. A. (1988). Management of forage plants-Cenchrus. In A. M. Peixoto, J. C. de Moura \& V. P. Faria (Eds.), Symposium on Pasture Management, Piracicaba, 1988, Annals (Vol. 9, pp. 219-230). Foundation of Agrarian Studies Luiz de Queiro (FEALQ).

Cook, B. G. (2007). Factsheet: Buffel grass. Pasture Australia. Retrieved from http://keys.lucidcentral.org/ keys/v3/pastures/Html/Factsheet\%20-\%20Buffel\%20grass.pdf

Dam, J. C., \& Malik, R. S. (Eds.). (2003). Water productivity of irrigated crops in Sirsa district, India. Integration of remote sensing, crop and soil models and geographical information systems (p. 173). WATPRO Final Report, Including CD-ROM.

Descheemaeker, K., Amede, T., Haileslassie, A., \& Bossio, D. (2010). Analysis of gaps and possible interventions for improving water productivity in crop-livestock systems of Ethiopia. Experimental Agriculture, 47(Suppl. 1), 21-38. https://doi.org/10.1017/S0014479710000797

Food and Agricultural Organization (FAO). (2003). Raising Water Productivity. Retrieved December 6, 2010, from http://www.fao.org/ag/magazine/0303sp2.htm

Koech, O. K., Kinuthia, R. N., Karuku, G. N., Mureithi, S. M., \& Wanjogu, R. (2016). Irrigation levels affects biomass yields and morphometric characteristics of range grasses in arid rangelands of Kenya. Springer Plus, 5, 1640. https://doi.org/10.1186/s40064-016-3309-8

Laidlaw, A. S. (2005). The relationship between tiller appearance in spring and contribution of dry matter yield in perennial ryegrass (Lolium perenne L.) cultivars differing in heading date. Grass Forage Sci., 60, 200-209. https://doi.org/10.1111/j.1365-2494.2005.00468.x

Lane, P. W., \& Payne, R. W. (1996). Genstat for windows: an introduction course. Statistics Department, IACR-Rothamsted, Harpenden, Herts, UK.

Lonsdale, W. M. (1994). Inviting trouble: Introduced pasture species in northern Australia. Australian Journal of Ecology, 19, 345-354. https://doi.org/10.1111/j.1442-9993.1994.tb00498.x

Mazahrih, N., Al Wahibi, H., Al Farsi, S., \& Ouled Belgacem, A. (2016). Yield and water productivity of Buffel and Rhodes grasses under different irrigation water regimes using the sprinkler line-source system. Grassland Science, 62, 112-118. https://doi.org/10.1111/grs.12120

Ministry of Agriculture and Irrigation, Yemen. (2011). Agricultural Statistics Year Book. Yemen.

Molden, D. (1997). Accounting for Water Use and Productivity. Colombo, Sri Lanka: International Irrigation Management Institute.

Owens, J., Bell, L., Rodriguez, D., Whitbread, A., Lawrence, J., \& Mann, M. (2008). Comparing the water use efficiency of tropical pasture grasses and legumes used in Queensland's mixed farming systems. Global Issues, Paddock Action. Proceedings of the 14th Australian Agronomy Conference, September 21-25, 2008, Adelaide.

Peden, D., Taddesse, G., \& Haileslassie, A. (2009). Livestock water productivity: Implications for sub-Saharan Africa. The Rangeland Journal, 31, 187-193. https://doi.org/10.1071/RJ09002

Sanderson, M. A., Voigt, P., \& Jones, R. M. (1999). Yield and quality of warm-season grasses in central texas. Journal of Range Management, 52, 45-50. https://doi.org/10.2307/4003508

Sharif-Zadeh, F., \& Murdoch, A. J. (2001). The effects of temperature and moisture on after-ripening of Cenchrus ciliaris seeds. Journal of Arid Environments, 49, 823-831. https://doi.org/10.1006/jare.2001.0820

Shideed, K., Oweis, T., Gabr, M., \& Osman, M. (2005). Assessing On-Farm Water-Use Efficiency: A New Approach (p. 86). ICARDA, Aleppo, Syria.

Shinde, A. K., Karim, S. A., Sankhyan, S. K., \& Bhatta, R. (1998). Seasonal changes in biomass growth and quality and its utilization by sheep on semiarid Cenchrus ciliaris pasture of India. Small Ruminant Research, 30, 29-35. https://doi.org/10.1016/S0921-4488(98)00087-X

Skinner, H. R., \& Moore, K. J. (2007). Growth and development of forage plant. In R. F. Barnes, C. J. Nelson, K. J. Moore, \& M. Collins (Eds.), Forages: The science of grassland agriculture (6th ed., pp. 53-66). Wiley-Blackwell, Ames. 


\section{Copyrights}

Copyright for this article is retained by the author(s), with first publication rights granted to the journal.

This is an open-access article distributed under the terms and conditions of the Creative Commons Attribution license (http://creativecommons.org/licenses/by/4.0/). 